\title{
The Effect of Dietary Tarragon (Artemisia Dracunculus) Powders in Different Levels on Carcass Characteristics and Some Internal Organ's Weight of Broiler Chickens
}

שuthor(s)
Yildirim $\mathrm{F}^{\prime}$
Tunç MA"
। Department of Animal Science, Faculty
of Veterinary Science, Atatürk University,
Turkey
" Department of Animal Science, Vocational
High School of Narman, Atatürk University,
Turkey

\section{Mail Address}

Corresponding author e-mail address Fatih Yildirim

Department of Animal Science, Faculty of Veterinary Science, Atatürk University,

Erzurum, TC, Turkey.

Tel: $\quad$ (+90) 4422317187

Email: fatihyildirim@atauni.edu.tr

\section{- Keywords}

Broiler chicks, Carcass, Internal Organs, Tarragon Powder.

\section{ABSTRACT}

This study was conducted to investigate the effects of different levels of Tarragon powder on head, chicken feet, some internal organs and carcass characteristics of broiler chickens. One day -old two hundred forty Ross 308 male broilers were randomly allocated into four treatments and six replicates per treatment. At each replicate ten birds were used. All birds at 42 days had ad libitum access to water and feed and were exposed to a 23L:1D lighting program. The diets were set on the basis of corn, soybean and wheat meal, formulated according to the recommendations of the Ross 308 manual (starter days 1-14, grower days 15-37, and finisher days 38-42), and offered as mash. The tarragon plant used in the research was purchased from a vegetable market in Erzurum province in Turkey. Treatments were: base diet (Control), base diet $+0.1 \%$ of Tarragon powder (group A), base diet $+0.2 \%$ of Tarragon powder (group B), base diet $+0.5 \%$ of Tarragon powder (group C). Except for relative wing and head weight, other carcass traits were not significantly affected $(p>0.05)$ by different levels of Tarragon powder. The lowest relative head weight $(p<0.001)$, and the highest relative wing weight $(p<0.05)$ were observed in the control group. The results of this study suggest that the addition of Tarragon powder to broiler diets has no effect on other important carcass traits, except for the head and wing weights of broiler chickens.

\section{INTRODUCTION}

Some feed supplement, including antibiotics, have been used extensively in the poultry sector in recent years. The excessive use of antibiotics, possible antibiotic residues in the livestock industry, and concerns about antibiotic resistance have been revealed. This has led to limitations on the use of antibiotics as a feed supplement and the search for alternative feed supplement in animal feed production (Rahimi et al., 2011). Limitations in the utilization of antibiotics as a growth stimulus in feeding the birds made researchers look for another feed supplement to improve animal's health and performance; accordingly poultry growth can economize (Hosseinzadeh et al., 2014).

Plants have been of great importance for years in increasing people's health and quality of life. Herbal medicine has natural ingredients that can promote healthy lifestyles and alleviate diseases. The World Health Organization predicted that nearly $80 \%$ of people would prefer traditional medicine as the first step when they wanted to benefit from health services. Most of these therapies contain the use of plant extracts or their active components (Craig, 1999).

Artemisia Dracunculus L. (Tarragon or Estragon), which belongs to Asteraceae (Baytop, 1984), known as "tarhun" in Anatolia, is a small shrubby perennial herb (Kordali et al., 2005). It also has an important 
class of biologically active substances in plants and, when its pharmacological properties was examined, it turned out to be medically noticeable, capable of affecting the brain and gastrointestinal tract function, as well as having a broad antimicrobial effect (Aglarova et al., 2008). There are no limitations to the use of Tarragon plant, because it is an essential oil of the nontoxic category and does not generate sensitization or irritation (Voitkevich, 1999).

Tarragon was used as a medication for increasing appetite in the early days, and its liquid extract can increase the secretion of gastric juice. The use of Tarragon in the diets is not a form meant to cover antacid influences, but to prepare the basis for the development of preservative factors such as bicarbonate production, mucin secretion, contraction property, or the gastric ant-helicobacter ability (Ribnichy et al., 2004).

There are only restricted experimental information about the consumption of Tarragon in fowl feeding (Hosseinzadeh \& Farhoomand, 2014; Hosseinzadeh \& Moghaddam, 2014; Hosseinzadeh et al. 2014). Recently, Tarragon leaves and its connected essential oils examined in broiler diets, and some useful results were observed in slaughter traits and growth performance (Gharetappe et al., 2015). Hence, the aim of this study was to research the effect of the dietary supplementation of Tarragon powder, in different levels, in the head, chicken feet, some internal organs and carcass characteristics of broiler chickens.

\section{MATERIALS AND METHODS}

This experiment was approved by Atatürk University Local Board of Ethics Committee for Animal Experiments (HADYEK decision no: 2014/20), and also funded by Ataturk University Scientific Research Projects (SRP-2013/277).

One day-old two hundred forty Ross 308 male broilers from a commercial hatchery were randomly allocated into four treatments and six replicates per treatment. In each replicate, ten birds were used in an environmentally-controlled room. House temperature was initially maintained at $32{ }^{\circ} \mathrm{C}$ and then gradually reduced to $23-24{ }^{\circ} \mathrm{C}$ for the remaining of the experimental period. Air relative humidity was mounted at $65 \%$. For 42 days, all of the birds had ad libitum access to water and feed and were exposed to a 23L:1D lighting program. The diets consisted of corn, soybean and wheat meal, formulated according to the recommendations of the Ross 308 manual, and offered as mash. The feedstuffs and nutrient composition of starter (days 1-14), grower (days 1537), and finisher (days 38-42) are presented in Table 1. Treatments were: base diet (Control), base diet + $0.1 \%$ of Tarragon powder (group A), base diet $+0.2 \%$ of Tarragon powder (group B), base diet $+0.5 \%$ of Tarragon powder (group C).

Table 1 - Composition and nutrient levels of starter, grower and finisher diets

\begin{tabular}{|c|c|c|c|}
\hline Ingredients (\%) & $\begin{array}{c}\text { Starter } \\
(1-14)\end{array}$ & $\begin{array}{c}\text { Grower } \\
(15-37)\end{array}$ & $\begin{array}{l}\text { Finisher } \\
(38-42)\end{array}$ \\
\hline Corn grain & 43.41 & 40.13 & 38 \\
\hline Soybean pulb (44\% CP) & 34.4 & 26.5 & 20.5 \\
\hline Wheat & 15.25 & 25.28 & 32.11 \\
\hline Soybean oil & 2 & 3.5 & 4.8 \\
\hline Dicalcium phosphate & 2.3 & 2 & 2 \\
\hline DL-methionine & 0.2 & 0.22 & 0.24 \\
\hline Lysine hydrochloride & 0.27 & 0.22 & 0.2 \\
\hline Limestone & 0.87 & 0.85 & 0.85 \\
\hline Salt & 0.3 & 0.3 & 0.3 \\
\hline Mineral and Vitamin Premix & 1 & 1 & 1 \\
\hline \multicolumn{4}{|c|}{ Calculated nutrient contents (\%) } \\
\hline ME (kcal/kg) & 2930 & 3110 & 3220 \\
\hline Crude protein & 22.5 & 20 & 18 \\
\hline Crude fiber & 3.15 & 3.5 & 3.7 \\
\hline Calcium & 0.97 & 0.86 & 0.85 \\
\hline Available phosphorus & 0.51 & 0.48 & 0.47 \\
\hline Lysine & 1.45 & 1.30 & 1.22 \\
\hline Methionine & 0.52 & 0.50 & 0.48 \\
\hline Methionine + cysteine & 0.90 & 0.81 & 0.73 \\
\hline
\end{tabular}

In this study, the Tarragon plant was purchased in July, from the vegetable market in Erzurum province in Turkey. After washing and removing the soil, plants and also nonusable parts of the herb, it was placed on a clean floor, and dried under appropriate room temperature. The dried tarragon samples were powdered in a mill, and were added to the experimental diets (Hosseinzadeh et al., 2014). Artemisia dracunculus also has important compounds attributed to it, such as: metilkafikol, osimen, mirsen, kamfer, kamfen, anisacit, $\alpha$-ve $\beta$-pinen, limonen, linalool, $p$-metoksisinamikaldehide, flavonoide, kumarine and minerals (Gülpınar, 2012).

The feed was withdrawn three hours before slaughter (Asadi et al., 2016). At the end of the trial (42 days old), two birds per each replica, whose body weights were nearest to the average body weight of their groups, were selected from every treatment (12 in treatment, 48 birds in total). After marking and noting specified treatment and replication's properties, 
they were weighed and then slaughtered by severing the jugular vein carcass to determine the carcass characteristics. After this the feathers, heads, chicken feets and inner organs (except kidneys and lungs) of the chickens were removed. The heads, chicken feets, hearts, livers, gizzards and hot carcasses were then weighed. The carcasses were kept at $+4^{\circ} \mathrm{C}$ for $24 \mathrm{~h}$ and were weighed cold posture; afterward the thighs (from articulatio coxae), wings (from articulatio humeri) and breasts (from articulatio sternocostal) were removed according to regulations and requirements of the Institute of Turkish Standards (Atasoy\& Aksoy, 2005). The organs were weighed with the skin (Seven et al., 2008). The head, chicken feet, some internal organs, and carcass were calculated about body weight at sacrifice.

Data concerning 4 diet groups in the mathematical model of carcasses traits and internal organs analyzed completely randomized design using GLM procedure of SPSS 20 statistical analysis of Tukey multiple range tests and variance were used to compare outcomes in unique groups. Statistical differences were considered to be significant when $p<0.05$.

\section{RESULTS AND DISCUSSION}

The effects of different levels of Tarragon powder on carcass traits are presented in Table 2. As shown in Table 2, the dietary supplementation of these compounds had no effect on carcass, thigh and breast yield percentages, but it did on wing yield. Among the four treatments, the control broilers presented the highest wing weight, which was significant on the treatment $0.1,0.2$, and $0.5 \% / \mathrm{kg}(\mathrm{p}<0.05)$. This finding was in agreement with a report of Hosseinzadeh et al. (2014) who did not detect any effect of Tarragon powder at levels of $0.125,0.25,0.5 \%$ of feed on carcass, thigh and breast yields. In contrast to Gharetappe et al.(2015), the highest carcass observed in this study, had the addition of $0.4 \%$ Tarragon leaves to broiler diets. This difference probably is related to the composition of experimental diets.

Table 2 - Effects of supplemental dietary Tarragon powder on some carcass traits of broiler chickens. (mean \pm standard deviation)

\begin{tabular}{|c|c|c|c|c|}
\hline Parameter $(\% / k g)$ & ${ }^{*}$ Carcass $(\%)$ & Thigh (\%) & Breast (\%) & Wing (\%) \\
\hline Control & $74.45 \pm 2.88$ & $28.48 \pm 1.31$ & $26.41 \pm 2.41$ & $9.34 \pm 1.27^{a}$ \\
\hline 0.1 & $72.91 \pm 6.49$ & $26.88 \pm 2.71$ & $26.81 \pm 3.31$ & $7.55 \pm 1.79^{b}$ \\
\hline 0.2 & $73.15 \pm 2.81$ & $27.98 \pm 1.43$ & $27.70 \pm 2.35$ & $8.17 \pm 1.96^{a b}$ \\
\hline 0.5 & $73.33 \pm 3.23$ & $26.25 \pm 3.39$ & $28.66 \pm 2.04$ & $8.06 \pm 1.01^{a b}$ \\
\hline Mean & $73.46 \pm 4.05$ & $27.40 \pm 2.46$ & $27.39 \pm 2.64$ & $8.28 \pm 1.65$ \\
\hline$p$ & 0.805 & 0.103 & 0.160 & 0.048 \\
\hline
\end{tabular}

Values with different superscripts in the same column for each section are significantly different $(p<0.05) .{ }^{*}$ : Cold carcass yields.

The head, chicken feet, and some internal organs relative weight are summarized in Table 3 . The results showed that chicken feet, heart, liver and gizzard relative weight were not affected by different levels of Tarragon powder. In agreement with our findings, Hosseinzadeh and Farhoomand (2014) observed that the use of Tarragon powder in broilers had no significant effects on the heart and liver relative weight. On the other hand, the higher yields in the heart and gizzard, and the lower liver yields observed in the present study is not consistent with the findings of Gharetappe et al.(2015), with the addition of $0.4 \%$ Tarragon leaves to broiler diets.

The results in Table 3 indicate that the relative head weight of the control group was significantly further down than that of the other groups $(p<0.001)$. In other words, the relative head weights increased with the increase in the level of concentrate in the

Table 3 - Effects of supplemental dietary Tarragon powder on head, chicken feet and some internal organs of broiler chickens. (mean \pm standard deviation)

\begin{tabular}{|c|c|c|c|c|c|}
\hline Parameter (\%/kg) & $\begin{array}{c}\text { Head } \\
(\%)\end{array}$ & Chickenfeet (\%) & $\begin{array}{c}\text { Heart } \\
(\%)\end{array}$ & $\begin{array}{c}\text { Liver } \\
(\%)\end{array}$ & Gizzard (\%) \\
\hline Control & $2.07 \pm 0.19 b$ & $3.09 \pm 0.28$ & $0.52 \pm 0.08$ & $2.28 \pm 0.34$ & $1.90 \pm 0.16$ \\
\hline 0.1 & $2.45 \pm 0.16 a$ & $3.41 \pm 0.58$ & $0.54 \pm 0.07$ & $2.09 \pm 0.30$ & $1.85 \pm 0.24$ \\
\hline 0.2 & $2.53 \pm 0.14 a$ & $3.51 \pm 0.54$ & $0.58 \pm 0.12$ & $2.19 \pm 0.34$ & $1.73 \pm 0.19$ \\
\hline 0.5 & $2.50 \pm 0.16 a$ & $3.04 \pm 0.20$ & $0.53 \pm 0.09$ & $2.03 \pm 0.18$ & $1.98 \pm 0.31$ \\
\hline Mean & $2.39 \pm 0.24$ & $3.26 \pm 0.46$ & $0.54 \pm 0.09$ & $2.15 \pm 0.30$ & $1.87 \pm 0.24$ \\
\hline$p$ & 0.000 & 0.065 & 0.430 & 0.168 & 0.080 \\
\hline
\end{tabular}

Values with different superscripts in the same column for each section are significantly different $(p<0.001)$. 
experiment's diet. Similar results were obtained by Eruvbetine et al. (2003) who reported higher head weight in broiler chickens, when compared with adding more concentrate cassava diet to the groups. But, no particular reason could be given for this in both experiments.

\section{CONCLUSIONS}

The results of the present study suggest that dietary supplementation in different levels of Tarragon powder to broiler chickens has a decreasing effect on wing weight and increasing effect on head weight of broiler chickens, but there are none significant impacts on other carcass traits. Therefore, it is suggested that further research is done considering how the use of Tarragon powder in broiler diets can affect poultry characteristics.

\section{REFERENCES}

Aglarova AM, Zilfikarov IN, Severtseva OV. Biological characteristics and useful properties of Tarragon (Artemisia dracunculus L.)(review). Pharmaceutical Chemistry Journal 2008;42(2):81-86.

Asadi $H$, Sadeghi AA, Eila N, Aminafshar M. Carcass traits and immune response of broiler chickens fed dietary L-Carnitine, coenzyme Q10 and ractopamine. Revista Brasileira de Ciência Avícola 2016;18(4):677-682.

Atasoy F, Aksoy T. The effects of sex separate rearing and early feed restriction of broiler chicks on carcass weight and valuable cuts. Veterinary Jounal of Ankara University 2005;52:53-56.

Baytop T. Therapy with medicinal plants in Turkey. Istanbul: Istanbul University Press; 1984.

Craig WJ. Health-promoting properties of common herbs. The American Journal of Clinical Nutrition 1999;70(3):491-499.

Eruvbetine D, Tajudeen ID, Adeosun AT, Olojede AA. Cassava (Manihot esculenta) leaf and tuber concentrate in diets for broiler chickens. Bioresource Technology 2003;86(3):277-281.
Gharetappe FK, Hassanabadi A, Semnaninezhad H, Nassiry MR. The effect of dietary Tarragon (Artemisia dracunculus) and Peppermint (Mentha piperita) leaves on growth performance and antibody response of broiler chickens. Iranian Journal of Applied Animal Science 2015;5(2):403-409.

Gülpınar Y. Research on the protective and therapeutic effects of Tarragon plant (artemissia drancunculus L.) against induced acute liver toxicity damage of wistar albino rats [thesis]. Gaziantep (TR): University of Gaziantep; 2012

Hosseinzadeh Z, Farhoomand P, Najafi R. Effects of Tarragon powders' different levels (Artemisia dracunculus) on performance and carcasses 'characteristics male broiler chickens. International Journal of Advanced Biological and Biomedical Research2014;2(5):1750-1760.

Hosseinzadeh, Z, Moghaddam G. Effects of Tarragon powders' different levels (Artemisia dracunculus) on general performance and anetometric properties of digestive system of male broiler chickens. International Journal of Advanced Biological and Biomedical Research 2014;2(5):1599-1605

Hosseinzadeh Z, Farhoomand P. The effects of Artemisia dracunculus' powders different levels on blood parameters and internal organs weight broiler chickens. International Journal of Advanced Biological and Biomedical Research 2014;2:661-668.

Kordali S, Kotan R, Mavi A, Cakir A, Ala A, Yildirim A. Determination of the chemical composition and antioxidant activity of the essential oil of Artemisia dracunculus and of the antifungal and antibacterial activities of Turkish Artemisia absinthium, A. dracunculus, Artemisia santonicum, and Artemisia spicigera essential oils. Journal of Agricultural and Food Chemistry 2005;53(24):9452-9458.

Rahimi S, Teymori Zadeh Z, Torshizi K, Omidbaigi R, Rokni H. Effect of the three herbal extracts on growth performance, immune system, blood factors and intestinal selected bacterial population in broiler chickens. Journal of Agricultural Science and Technology 2011;13:527-539.

Ribnichy DM, Poulev A, Oneal $Y$, Wnorowski $G$, Malek $D E$, Jager $R$, et al.Toxicological evaluation of the ethanolic extract of Artemisia dracunculus L.for use as a dietary supplement and in functional foods. Food and Chemical Toxicology 2004;42:585-598.

Seven PT, Seven I, Yılmaz M, Simşek ÜG. The effects of Turkish propolis on growth and carcass characteristics in broilers under heat stress. Animal Feed Science and Technology 2008;146(1):137-148.

Voitkevich SA. Essential oils for perfumes and aromatherapy. Moscow: Pishchevaya Promyshlennostc; 1999. 